\title{
DINAMIKA PSIKOLOGIS PERILAKU SEKS PRANIKAH MAHASISWA PELAKU SADOMASOCHISM
}

\author{
1Kholidiyah Fadlilah dan ${ }^{2}$ Iin Tri Rahayu \\ 1,2UIN Maulana Malik Ibrahim Malang \\ ${ }^{1}$ kholidiyahf@yahoo.co.id \\ 2lintri18@gmail.com
}

\section{Abstract}

Psychological dynamics of premarital sex behavior: case studies of students with sadomasochism are the dynamics that cause subjects to get used to premarital sex, as well as the psychological dynamics that occur and experienced by subjects in doing sadomasochism.This study aims to determine the psychological dynamics of premarital sex behavior: a case study on students with sadomasochism. This research was conducted using qualitative methods with a case study approach. The subjects of this study were subjects who had premarital sex and had a tendency towards the behavior of Sadomasochism. This study uses data collection methods with in-depth interviews and observations. The results of the research analysis can be concluded that triadic reciprocal causation starts from the initial environment given by the boyfriend to have sexual relations to form another personality through a process of thinking to feel pleasure and the emergence of an affiliate need in the subject and then produce behavior by following and receiving treatment from her boyfriend to do premarital sexual relations. The process of cognition which then continues to human agency, where the subject feels satisfied in having sexual relations, enjoys pain during sexual intercourse because of being hurt and hurting in sexual intercourse and addiction to sexual intercourse she does even though the subject experiences fear of parents, friends, fear of pregnancy is a traumatic form from the past. Also the disappearance of the figure of the older brother who is the main cause of the deviant behavior that has been carried out by the subject. Of all the behavior then the subject regulates themselves with the desire to repent and effort by using long clothes to cover the genitals.

Keywords: Human Agencies, Satisfaction, Addiction, Cognition, Affiliate Need, Premarital Sex Behavior, Fear, Self Regulation, Sadomasochism, Case Studies, Triadic Reciprocal Causation

\section{Abstrak}

Dinamika psikologis perilaku seks pranikah mahasiswa pelaku sadomasochism adalah dinamika yang menyebabkan subyek terbiasa melakukan seks pranikah, serta dinamika psikologi yang terjadi dan dialami subyek dalam melakukan sadomasochism. Penelitian ini dilakukan menggunakan metode kualitatif dengan pendekatan studi kasus. Adapun subyek penelitian ini adalah subyek yang 
melakukan hubungan seks pranikah dan memiliki kecenderungan terhadap perilaku Sadomasochism. Penelitian ini menggunakan metode pengambilan data dengan wawancara mendalam dan observasi. Hasil analisis penelitian dapat disimpulkan bahwa triadic reciprocal causation berawal dari lingkungan awal yang diberikan oleh pacar untuk melakukan hubungan seksual membentuk pribadi yang lain melalui proses berfikir merasakan kenikmatan dan munculnya need afiliasi dalam diri subyek dan kemudian menghasilkan perilaku dengan mengikuti dan menerima perlakuan dari pacarnya untuk melakukan hubungan seksual pra nikah. Proses kognisi yang kemudian berlanjut pada agensi manusia, dimana subyek merasa puas dalam melakukan hubungan seksual, menikmati rasa sakit saat melakukan hubungan seksual karena adanya menyakiti dan disakiti dalam melakukan hubungan seksual serta kecanduan dengan hubungan seksual yang dilakukannya meski subyek mengalami ketakutan terhadap orang tua, teman, takut hamil merupakan bentuk traumatik dari masa lalu. Juga hilangnya sosok figur kakak yang menjadi penyebab utama terjadinya perilaku menyimpang yang telah dilakukan oleh subyek. Dari kesemua perilakunya kemudian subyek meregulasi diri dengan adanya keinginan untuk bertaubat dan usaha untuk menggunakan pakaian serba panjang untuk menutup aurat.

Kata Kunci: Agensi Manusia, Kepuasan, Kecanduan, Ketakutan, Kognisi, Need Afiliasi, Perilaku Seks, Pranikah, Regulasi Diri, Sadomasochism, Studi Kasus, Triadic Reciprocal Causation

\section{PENDAHULUAN}

Sadomasochism (sadomasokis) merupakan perilaku memberi atau menerima kenikmatan yang bersifat seks dengan cara menyebabkan menderita rasa sakit. Istilah sadomasochism (sadomasokis) berasal dari kata "sadis" dan "masokhis" yang secara terpisah memiliki makna spesifik, apabila ia lebih menikmati perannya sebagai pihak yang menyakiti (aktif), maka ia disebut sadis, sedangkan jika ia lebih menikmati perannya sebagai pihak yang disakiti (pasif), maka ia disebut masokis. Point utama sadomasochism (sadomasokis) adalah kebutuhan untuk mengontrol dan keinginan untuk dikontrol. Penderita sexual sadisme dan sexual masochism (dalam The American Psychiatric Association's Diagnostic and Statistical Manual of Mental Disorders, DSM-IV-TR, 1994) pasien melaporkan munculnya dorongan seks berulang yang intens dan membangkitkan fantasi seks yang melibatkan tindakan tersebut (nyata) dimana penderita psikologis atau fisik (termasuk penghinaan) terhadap seseorang secara seks membangkitkan orang lain. Gejala harus ada paling sedikit 6 bulan. Individu 
dengan kondisi seperti ini dapat mewujudkan fantasinya dengan mencari pasangan yang sejalan, istri dengan kelainan masokistik atau bisa juga pekerja seks. Namun bagaimana jika hal tesebut terjadi pada sepasang kekasih yang belum menikah? Perilaku seks pranikah yang mengalami penyimpangan, baik dari segi agama maupun segi seksualitasnya. Perilaku seks pranikah yang telah terjadi kepada subyek dapat dimotivasi oleh rasa sayang dan cinta yang didominasi oleh perasaan kedekatan dan gairah yang tinggi terhadap pasangannya, tanpa disertai komitmen yang jelas.

Seotjiningsih (2006) menyebutkan bahwa faktor-faktor yang mempengaruhi perilaku seks pranikah remaja adalah hubungan orangtua remaja, tekanan negatif teman sebaya, Pemahaman tingkat agama (religiusitas), dan ekspos media pornografi memiliki pengaruh yang signifikan, baik langsung maupun tidak langsung terhadap perilaku seks pranikah remaja. Sigmund Freud (1896) mengatakan bahwa dorongan seks yang diiringi oleh nafsu atau libido telah ada sejak terbentuknya Id. Namun dorongan seks ini mengalami kematangan pada usia remaja. Selain itu, energi seks atau libido/nafsu pun telah mengalami perintisan yang cukup Panjang. Dorongan-dorongan yang muncul sebagai akibat dari perubahan aspek seksualitasnya menuntut untuk dipuaskan sekaligus menjadi hal yang bertentangan dengan agama (Daradjat, 1976). Religiusitas dapat menjadi faktor pelindung terhadap terjadinya perilaku seks pranikah. Individu yang menerima banyak faktor pelindung maka akan menurunkan faktor resikonya. Hal ini terlihat dari remaja yang memiliki kecenderungan mengarah pada aktivitas seks, jika mereka terikat dan memiliki batasan dalam sebuah organisasi sosial yang memegang prinsip norma mengenai perilaku yang tidak sesuai dengan norma seperti perilaku seks pranikah, mereka akan termotivasi untuk menunda atau menghindari perilaku seks (Crockett, Bingham, Chopak, \& Vicary, 1996 dalam Hardy \& Raffaelli, 2003). Namun hal tersebut justru berbeda dari hasil observasi kepada subyek yang dulunya adalah seorang santriwati di pondok pesantren dan juga siswa di Madrasah Ibtidaiyah hingga Aliyah dan berada dalam lingkungan pesantren yang notabene religiusitasnya tinggi, akan tetapi subyek masih melakukan perilaku seks pranikah dengan pasangannya.

Perilaku seks yang telah terjadi antara subyek dan pasangannya menimbulkan beberapa dampak yang merugikan di awal hubungannya, diantaranya muncul perasaan takut dan cemas. Sarwono (2007) menjelaskan selain menimbulkan dampak yang negatif, seks pranikah juga dapat mengakibatkan terganggunya hubungan seseorang dilingkungan masyarakat seperti dikucilkan oleh teman, hilangnya rasa percaya terhadap laki-laki, khawatir tidak ada lagi yang mau dengan dirinya, menjadi penyuka sesama jenis. Dampak negatif yang dirasakan oleh individu yang melakukan seks pranikah menimbulkan 
rasa bersalah yang mendalam. Meskipun subyek mengerti terhadap resiko yang akan diterimanya dengan hubungan yang telah dijalani selama ini. subyek mengaku tidak bisa berhenti dari kebiasaan seksnya. Bahkan subyek merasakan badmood, kurang fokus, tidak semangat jika subyek tidak melakukan hubungan seks. Dan dari sinilah peneliti merasa bahwa apa yang dialami subyek merupakan suatu keunikan yang menjadikan perlu adanya sebuah penelitian. Bagaimana dinamika psikologis perilaku seks pranikah pelaku sadomasochism (sadomasokis) dan adanya suatu batasan masalah dalam sisi kognisi- afeksinya dengan tujuan untuk memahami tentang dinamika psikologis perilaku seks pranikah pelaku sadomasochism (sadomasokis). Adapun manfaat dari penelitian ini ialah terdapat empati lebih terhadap fenomena seks pranikah oleh berbagai pihak, khususnya orang tua, remaja dan peneliti selanjutnya. Soetjiningsih (2008) mengungkapkan bahwa, perilaku seks pranikah adalah segala tingkah laku seks yang didorong oleh hasrat seks dengan lawan jenisnya dalam keadaan belum menikah. Menurut Mu'tadin (dalam Rediekan \& Respati, 2013), perilaku seks pranikah adalah perilaku seks yang dilakukan tanpa melalui proses pernikahan resmi menurut agama dan kepercayaan tiap- tiap individu. Begitu pula dengan Crooks (dalam Nuandri \& Widayat, 2014) yang mendefinisikan perilaku seks pranikah sebagai perilaku yang mengarah pada keintiman heteroseks yang dilakukan oleh sepasang laki-laki dan perempuan sebelum adanya ikatan resmi (pernikahan).

Purnomowardani dan Koentjoro (2000) mengatakan bahwa, perilaku seks pranikah adalah manifestasi dari adanya dorongan seks yang dapat diamati secara langsung melalui perbuatan yang tercermin dalam tahap-tahap perilaku seks dari tahap yang paling ringan hingga tahap yang paling berat yang dilakukan sebelum adanya ikatan pernikahan yang sah. Perilaku seks pranikah adalah segala tingkah laku yang didorong oleh hasrat seks dengan bentuk tingkah laku seks yang beraneka ragam, mulai dari berkencan, bercumbu, dan bersenggama yang dilakukan oleh dua orang, pria dan wanita, diluar perkawinan yang sah (Sarwono, 2008). Simanjuntak (dalam Prastawa \& Lailatushifah, 2009) juga menyatakan bahwa, perilaku seks pranikah adalah segala macam tindakan seperti bergandengan tangan, berciuman sampai dengan bersenggama yang dilakukan dengan adanya dorongan hasrat seks yang dilakukan sebelum adanya ikatan pernikahan yang sah.

Berdasarkan beberapa pendapat tokoh dapat disimpulkan, bahwa perilaku seks pranikah adalah segala tingkah laku seks yang didorong oleh hasrat sepasang laki-laki dan perempuan yang dilakukan tanpa melalui proses pernikahan resmi menurut agama dan kepercayaam tiap individu yang mengarah pada keintiman 
heteroseks dari tahap yang paling ringan hingga tahap yang paling berat, seperti: bergandengan tangan, berciuman, sampai bersenggama.

Sadomasochism (sadomasokis) merupakan perilaku memberi atau menerima kenikmatan yang bersifat seks dengan cara menyebabkan menderita rasa sakit. Istilah sadomasochism (sadomasokis) berasal dari kata "sadis" dan "masokhis" yang secara terpisah memiliki makna spesifik, apabila ia lebih menikmati perannya sebagai pihak yang menyakiti (aktif), maka ia disebut sadis, sedangkan jika ia lebih menikmati perannya sebagai pihak yang disakiti (pasif), maka ia disebut masokis. Meskipun demikian, pelaku sadomasochism (sadomasokis) menggambarkan diri mereka sebagai BDSM (Bondage and Discipline Sadism and Masochism) secara bergantian, BDSM berasal dari kata bondage (perbudakan) dan discipline pendisiplin), serta sadism (sadisme) dan masochism (masokisme) yang menikmati seks dengan cara menyakiti atau disakiti pasangan.

\section{LANDASAN TEORI}

\section{a. Sadisme}

Sadisme adalah salah satu jenis dari Paraphilia. (Dalam DSM-IV-TR, 1994) Parafilia merupakan sekelompok gangguan yang mencakup ketertarikan seks terhadap objek yang tidak wajar atau aktivitas seks yang tidak pada umumnya. Gangguan sadisme adalah gangguan tertentu dimana gairah seks terjadi dari penderitaan fisik atau psikologis individu lain (dalam The American Psychiatric Association, 2013). Menurut Krafft-Ebing, Kekerasan sadis menuntut patologi seks dan kepribadian pada pelaku. Dia adalah orang pertama yang mengajukan hubungan antara kekejaman, kekerasan, dan nafsu (Kirsch \& Becker, 2007; KrafftEbing, 1886/1965).

\section{b. Masokhis}

Masochism atau masokhis merupakan salah satu bentuk parafilia yang memiliki karakteristik yang telah disebutkan (dalam DSM IV TR, 1994) yaitu berulang, intens, terjadi selama periode minimal 6 bulan, fantasi, dorongan, perilaku yang menimbulkan gairah seks yang berkaitan dengan tindakan (bukan fantasi) mempermalukan atau menyebabkan penderitaan fisik pada orang lain, menyebabkan distress pada orang yang bersangkutan dalam fungsi sosial atau pekerjaan atau orang tersebut bertindak berdasarkan dorongannya pada orang lain yang tidak menghendakinya (The American Psychiatric Association, 2013).

Perilaku masokhis sering dikaitkan dengan perilaku sadisme karena mayoritas sadisme menjalin hubungan dengan masokhis untuk memperoleh kepuasan seks secara timbal balik. Dari hal tersebut muncullah istilah 
sadomasokhis, istilah tersebut berasal dari dua pengarang subjek yakni Marquis de Sade dan Leopold von Sacher- Masoch. Sade (1740-1814), seorang bangsawan sekaligus tentara berkebangsaan Prancis pada abad ke-18 yang terkenal. Seseorang yang memperoleh kepuasan seks dengan cara menyiksa pasangannya dengan kejam. Sadisme dapat memperoleh kenikmatan orgasmic sempurna dengan menimbulkan rasa sakit pada pasangannya sedangkan masokhis dapat terpuaskan ketika membiarkan dirinya disakiti atau direndahkan.

Perilaku seks yang dilakukan sadisme dan masokhis bermakna fiksional dan sangat terencana yaitu aktivitas tersebut disusun dalam sebuah cerita dengan berbagai aturan dan prosedur yang disepakati bersama. Disakiti, dipermalukan, dan didominasi adalah bagian dari kesepakatan yang diperankan. Masokhisme melibatkan situasi mengikat atau menyakiti diri sendiri pada saat masturbasi atau berfantasi seks. Selain itu, pasangan juga diminta untuk mengikat (membatasi gerak), menutup mata (membatasi visual), memukul dan bahkan mencambuk.

Perilaku masokhisme seks yang paling berbahaya adalah hipoksifilia, dimana partisipan terangsang secara seks dengan mengurangi mengkonsumsi oksigen, misalnya dengan menggunakan jerat, kantung plastik, bahan kimia, atau tekanan pada dada. Pengurangan oksigen ini juga disertai dengan fantasi sesak nafas atau dengan dibuat sesak nafas oleh pasangan dan baru menghentikan aktivitas ini sebelum kehilangan kesadaran namun terkadang kematian karena kehabisan nafas juga terjadi akibat salah perhitungan.

Berdasarkan penjabaran diatas, sadomasochism (sadomasokis) ialah perilaku memberi atau menerima kenikmatan yang bersifat seks dengan cara menyebabkan menderita rasa sakit. Berulang, intens, terjadi selama periode minimal 6 bulan, fantasi, dorongan, perilaku yang menimbulkan gairah seks yang berkaitan dengan tindakan (bukan fantasi) mempermalukan atau menyebabkan penderitaan fisik pada orang lain, menyebabkan distress pada orang yang bersangkutan dalam fungsi sosial atau pekerjaan atau orang tersebut bertindak berdasarkan dorongannya pada orang lain yang tidak menghendakinya. Mayoritas sadisme menjalin hubungan dengan masokhis untuk memperoleh kepuasan seks secara timbal balik.

Albert Bandura menekankan kejadian-kejadian yang tidak disengaja walaupun juga menyadari bahwa pertemuan dan kejadian itu tidak selalu mengubah jalan hidup seseorang. Teori kognitif sosial memiliki beberapa asumsi dasar. Pertama, karakteristik yang paling menonjol dari manusia adalah plastisitas; yaitu bahwa manusia mempunyai fleksibilitas untuk belajar berbagai jenis perilaku dalam situasi yang berbeda-beda. Bandura setuju dengan Skinner bahwa manusia mampu dan betul-betul belajar melalui pengalaman langsung, 
tetapi Bandura lebih menekankan terhadap proses belajar dengan cara diwakilkan (vicarious learning), yaitu belajar dengan mengobservasi orang lain. Bandura juga menekankan bahwa penguatan dapat bersifat tidak langsung; manusia dapat memperoleh penguatan dengan mengobservasi orang lain menerima suatu hadiah (reward). Penguatan secara tidak langsung ini menjelaskan banyak bagian dari proses belajar manusia.

Kedua, melalui model triadic reciprocal caunsation yang meliputi perilaku, lingkungan dan faktor pribadi. Dapat terlihat bahwa manusia mempunyai kapasitas untuk mengontrol kehidupannya. Manusia dapat mengubah kejadian yang tidak menetap menjadi suatu metode yang cukup konsisten dalam mengevaluasi serta mengontrol lingkungan sosial dan budaya mereka. Tanpa kapasitas ini manusia hanya akan bereaksi terhadap pengalaman sensoris dan akan kekurangan kapasitas untuk menganisipasi peristiwa-peristiwa, menciptakan gagasan baru, atau menggunakan standar internal mereka untuk mengevaluasi peristiwa yang sedang terjadi. Dua dorongan lingkungan yang penting dalam model triadi adalah pertemuan yang kebetulan dan kejadian tidak disengaja.

Ketiga, teori kognitif sosial menggunakan perspektif agen, yaitu manusia mempunyai kapasitas untuk mengontrol sifat dan kualitas hidup mereka. Manusia adalah produsen sekaligus produk dari sistem sosial. Komponen penting dari model triadic reciprocal caunsation adalah efikasi diri. Performa manusia secara umum akan meningkata saat mereka memiliki efikasi diri yang tinggi; yaitu kepercayaan bahwa mereka dapat melakukan suatu perilaku yang akan menghasilkan peilaku yang diinginkan dalam suatu situasi yang khusus. Sebagai tambahan dari efikasi diri, kedua agen proxy dan efikasi diri dapat memprediksikan performa. Dengan agen proxy, manusia mampu bersandar pada orang lain untuk barang-barang dan layanan-layanan, sementara efikasi kolektif merujuk pada keyakinan yang dimiliki oleh banyak orang, yang dapat menyebabkan perubahan.

Keempat, manusia mengontrol tingkah lakunya berdasarkan faktor- faktor internal dan eksternal. Faktor eksternal meliputi lingkungan fisik, dan sosial dari seseorang, sementara faktor internal meliputi observasi diri, proses menilaidan reaksi diri. Kelima, saat seseorang menemukan dirinya dalam situasi yang ambigu secara moral, mereka biasanya berusaha untuk mengontrol perilaku mereka melalui agensi moral, yang meliputi mendefinisikan ulang suatu perilaku, merendahkan atau mendistorsi konsekuensi dari perilaku mereka, melakukan dehumanisasi atau menyalahkan korban dari perilaku mereka dan mengalihkan atau mengaburkan kewajiban atas tindakan mereka. 


\section{METODE PENELITIAN}

Penelitian ini digunakan Metodologi dengan pendekatan kualitatif, yang mempunyai karakteristik alami (natural setting) sebagai sumber data langsung, deskriptif, proses lebih dipentingkan dari pada hasil, analisis dalam penelitian kualitatif cenderung dilakukan secara analisa induktif serta makna merupakan hal yang esensial. Dalam hal ini penelitian yang digunakan yakni penelitian studi kasus (case study), yaitu: penelitian studi kasus menurut Yin (2011:2) adalah untuk menjelaskan bagaimana keberadaan dan mengapa kasus tersebut terjadi. Penelitian studi kasus bukan sekedar menjawab pertanyaan penelitian tentang 'apa' (what) obyek yang diteliti, tetapi lebih menyeluruh dan komprehensif lagi adalah tentang 'bagaimana' (how) dan 'mengapa' (why). Sumber data utama dalam penelitian ini yaitu kata-kata yang merupakan hasil wawancara kepada subyek. Data sekunder dalam penelitian ini adalah data yang diperoleh bukan secara langsung dari sumbernya. Dalan penelitian ini sumber data sekunder yang dipakai adalah significant others yang merupakan teman dekat subyek berjumlah satu orang. Adapun sumber tambahan, seperti alat record dan catatan saat wawancara. Dalam penelitian ini, metode yang digunakan adalah wawancara mendalam dan observasi. Wawancara mendalam merupakan kegiatan untuk mendapatkan informasi dari para informan dengan cara tatap muka atau bertemu langsung.

Pedoman wawancara disusun terlebih dahulu dan dapat dikembangkan sesuai dengan keadaan di lapangan. Dokumentasi pada saat wawancara, sehingga data-data yang dibutuhkan dalam penelitian bisa terkumpul secara maksimal. "Rekaman" sebagai setiap tulisan/pernyataan yang dipersiapkan oleh atau untuk individual atau kelompok dengan tujuan membuktikan adanya suatu peristiwa.

Analisis data merupakan salah satu langakah penting dalam rangka memperoleh temuan-temuan hasil penelitian. Setelah semua data terkumpul, maka langkah selanjutnya adalah pengelolahan dan analisa data. Yang dimaksud dengan analisis data ialah proses mencari dan menyusun secara sistematis data yang diperoleh dari hasil wawancara dengan cara mengorganisasikan data ke dalam kategori, menjabarkannya ke dalam unit-unit, melakukan sintesa, menyusunnya ke dalam pola, memilih mana yang penting dan akan dipelajari, serta membuat kesimpulan sehingga mudah dipahami oleh dirinya sendiri atau orang lain.

\section{HASIL PENELITIAN}


A berasal dari keluarga dengan standart ekonomi menengah ke atas. A tinggal di rumah yang terpisah oleh Ayahnya dan hanya tinggal Bersama ibu. Hal ini menjadikan pola asuh ibu yang cenderung lebih membebaskan. Demokratis, dalam arti anak berhak menentukan jalan hidupnya, dengan demikian mampu membuat A menjadi lebih mandiri. Tak terlepas dari semua itu melihat kondisi rumah A yang sering dikunjungi oleh orang lain, ibu memberikan pembelajaran seksual sejak dini mengingat dahulu A adalah gadis kecil yang senang sekali bermain air di depan rumah tanpa busana sambal menyanyi. Yang diajarkan ibu ialah perihal Batasan daerah yang boleh disentuh oleh orang lain dan menunjukkan bagian badan yang tidak boleh disentuh oleh orang lain. Selebihnya tidak ada pembelajaran yang lebih lanjut.

A menjalani hubungan dengan B (pacar) sejak ia duduk di bangku SMA. Hubungan tersebut berjalan ketika A duduk di kelas 3 SMA. A menjelaskan sejak SMA tidak pernah tidak menjalin hubungan dengan lawan jenis (menjomblo), sampai pada akhirnya terakhir menjalin hubungan dengan B. Mulanya A menjalani hubungan hanya 1 minggu dengan $B$, dengan alasan karena takut maka memutuskan untuk mengakhiri hubungan. Kemudian berlanjut sebelum A mengikuti ujian nasional A kembali menjalin hubungan dengan B. Sejak saat itu hubungan keduanya kian berlanjut mesra dan mulai bisa saling menjaga, B yang mampu menjaga perasaan $A$, menjaga agar bagaimana caranya tidak tersakiti hingga menjaga dari kontak fisik yang berlebihan dengan sebatas berpegangan tangan. Berdasarkan dari kontak fisik yang sebatas berpegangan tangan itu berlanjut pada kontak fisik yang lainnya. Hingga akhirnya kontak fisik tersebut sudah melewati batas normal. Dan saat itu B mengajak A untuk melakukan hubungan seksual di usianya yang masih 16 tahun dengan status siswa SMA.

A beranggapan hanya ingin membahagiakan B lantaran menjalin hubungan dengan dasar atas nama cinta. Berulang kali A \& B melakukan hubungan seksual dengan berbagai macam metode dan pola hal tersebut mengakibatkan A menjadi merasa bahwa hubungan seksual merupakan suatu kebutuhan yang harus terpenuhi. A mampu menikmati perilaku seks yang diberikan oleh $B$ dalam melakukan hubungan seksualnya dengan menggunakan metode yang keras. A melakukan hubungan seks dengan B. A yang tidak mengetahui bagaimana dalam berhubungan seks tersebut hanya mengikuti dan menerima setiap perlakuan yang diberikan oleh B. A menjelaskan kondisi dimana tahapan awal kontak fisik dengan B yang diawali dengan berpegangan tangan di awal hubungannya kemudian B mengajak berciuman yang saat itu dirasakan A muncul perasaan deg-degan (ndredeg) dan kemudian berlanjut dengan 
berciuman dan memegang payudara dan terus berlanjut hingga ke kemaluan sampai pada akhirnya melakukan hubungan seksual. Hubungan A \& B terus berkelanjutan hingga saat ini A sudah menjadi mahasiswa tingkat akhir di salah satu kampus di Kota Malang. Seiring berjalannya waktu A merasakan adanya kepuasan tersendiri setelah melakukan hubungan seksual dengan B. Perilaku tersebut terus berulang hingga menjadi suatu kebutuhan dalam kehidupan A. Adapun metode yang digunakan saat melakukan hubungan seksual dengan beberapa pola, mulai dari : atas bawah, doggy, 69 yang biasanya dilakukan oleh orang-orang pada umumnya dengan ritme pelan. Namun, perilaku tersebut berubah menjadi ritme keras, dalam artian melakukan hubungan seksual dengan cara menyakiti dan disakiti. Mulanya A merasa kesakitan dan ingin mengganti dengan metode yang biasa saja, namun B terus memaksa dan melakukan hal tersebut kepada A. Sampai pada akhirnya A mampu menikmati hubungan seksual dengan metode keras atau disakiti hingga orgasme dan A merasa dirinya menyukai metode tersebut.

A merasakan bahwa dirinya merasa kecanduan dengan hubungan seksual yang telah ia lakukan sejak SMA hingga saat ini. A mengaku menginginkan melakukan hubungan seksual dengan B jika satu minggu tidak bertemu dengan B. A bisa melakukan hubungan seksual dengan B 2 hari sekali, jikalau dirasa belum puas, maka akan ditambah lagi. Dalam satu kali permainan bisa sampai 3-4 ronde, bergantung pada kekuatan masing-masing. A menjelaskan dalam hubungan seksualnya dirasa akhir- akhir ini terasa begitu cepat. Dalam artian durasi waktu yang sebentar, kemungkinan waktu 1 jam. A juga menjelaskan bagaimana kondisi cepat atau duurasi waktu yang sebentar tersebut. Kondisi saat melakukan hubungan seksual diraa tidak menentu. Biasanya, ronde pertama cepat, 2,3,4 itu terasa lama. A menjelaskan bahwa saat kondisi tersebut B mempunyai lahan tersendiri untuk mengatur frekuensi bermainnya. Pada saat ronde selanjutnya B mampu menempatkan dirinya disaat tertentu diwaktu tertentu yang mana semua itu tak terduga. Dan pada saat menunggu dari ronde 1 ke ronde berikutnya A \& B mengisi dengan bermain seperti mencium, memainkan payudara dan sebagainya. Dan A menambahkan bahwa kondisi seksnya berada diangka 8 dengan intensitas melakukan hubungan seksual berada diangka 99,9. Hubungan seksual yang tengah dijalani oleh A \& B telah berlangsung lama. A sering kali merasa takut hamil jika setiap kali telat menstruasi. A bermaksud untuk berhijrah dengan mencoba menggunakan pakaian yang Panjang dan menutup aurat. Dengan kondisi tersebut A selalu berpikiran untuk bertaubat dan menyudahi hubungan terlarang yang tengah ia jalani dengan B. Sebelum A mengenal B, A memiliki saudara tiri laki-laki 
yang begitu sayang terhadapnya dan selalu ada disaat A membutuhkannya. Kedekatan itu mengalir mulai sejak A kecil hingga A menginjak bangku SMP. Tepat di bangku kelas 3, A merasakan ada hal yang begitu aneh terjadi kepada saudara laki-lakinya, sehingga sejak saat itulah hubungan antara kakak beradik itu perlahan memudar hingga saat ini tidak ada kejelasan mengenai kondisi yang sebenarnya. Dari sinilah A merasa kehilangan sosok kakak yang dulunya selalu ada dan yang mampu menyayanginya, perhatian dan menjaganya. Hingga kemudian A bertemu dengan $\mathrm{B}$ yang mana $\mathrm{B}$ adalah sosok lelaki yang mampu menggantikan posisi saudara laki-lakinya yang telah kian menjauh. A melakukan hubungan seks dengan B muncullah rasa ketakutan yang terus menghantui. Takut hamil, takut orang tua, takut tidak memiliki teman, takut dibicarakan oleh orang lain, hingga takut tes keperawanan. A merasakan adanya kepuasan tersendiri setelah melakukan hubungan seksual dengan B. Perilaku tersebut terus berulang hingga menjadi suatu kebutuhan dalam kehidupan A. Adapun metode yang digunakan saat melakukan hubungan seksual dengan beberapa pola, mulai dari : atas bawah, doggy, 69 yang biasanya dilakukan oleh orang-orang pada umumnya dengan ritme pelan. Namun, perilaku tersebut berubah menjadi ritme keras, dalam artian melakukan hubungan seksual dengan cara menyakiti dan disakiti. Mulanya A merasa kesakitan dan ingin mengganti dengan metode yang biasa saja, namun $B$ terus memaksa dan melakukan hal tersebut kepada A. Sampai pada akhirnya A mampu menikmati hubungan seksual dengan metode keras atau disakiti hingga orgasme dan A merasa dirinya menyukai metode tersebut.

\section{PEMBAHASAN}

Orang tua jaman sekarang memilih untuk memasukkan anaknya ke dalam pondok pesantren. Dengan alasan agar terdidik dan menjadi manusia yang jauh lebih baik daripada orang tuanya. Namun apa yang terjadi setelah anak keluar dari pesantren terlebih tanpa ada pengawasan orang tua. Tidak menutup kemungkinan pergaulan bebas membabi buta anak muda zaman sekarang. Lantaran ingin di akui kedewasaanya ia menjadikan dirinya sebagai pelaku yang menerapkan perilaku seksual pranikah. Hal ini terjadi kepada subyek yang dulunya seorang santri, tinggal dalam lingkungan pondok pesantren, bersekolah di Madrasah dan memiliki keluarga yang utuh. Keluarga menjadi acuan utama dalam menjelajahi kehidupan. Terutama ketika seorang anak jauh dari orang tua. Banyak hal yang bisa dilakukan oleh anak ketika sudah keluar dari rumah. Namun sejak ia jauh dari pengawasan orang tua, subyek melakukan hubungan seksual Bersama B (pacar) yang disebut dengan perilaku seks pranikah. Soetjiningsih (2008) mengungkapkan bahwa, 
perilaku seks pranikah adalah segala tingkah laku seks yang didorong oleh hasrat seks dengan lawan jenisnya dalam keadaan belum menikah.

Sebelum subyek menjalin hubungan dengan pacarnya, subyek menjelaskan bahwa sebenarnya subyek memiliki saudara tiri seorang laki-laki yang sejak kecil subyek merasa sangat dekat hingga subyek tumbuh besar. Namun saat subyek duduk bangku SMP, subyek merasa saudara laki- lakinya menjauh dan perlahan menghilang. Sejak saat itu subyek merasa kehilangan sosok figur seorang kakak laki-lakinya yang dulunya selalu ada, menyayangi dan selalu menjaganya. Sampai kemudian datang B (pacar subyek) yang menemani subyek. Yang dirasa saat itu, subyek seperti menemukan sosok kakak laki- lakinya yang telah hilang kemudian datang kembali dan memberikan kasih sayang sama seperti kakaknya. Kedekatan subyek dan pacarnya terus berkelanjutan hingga pada akhirnya subyek mencurahkan segalanya kepada pacar. Sampai pada akhirnya terjadi hubungan seksual pranikah.

\section{Faktor Pengaruh}

Berdasarkan teori bandura yang menjelaskan tentang kognitif sosial memiliki 5 asumsi dasar yang mana dalam penelitian ini menunjukkan terdapat beberapa tahap yang terjadi pada subyek, diantara ialah : belajar aktif, triadic reciprocal causation, agen manusia dan regulasi diri. Dalam belajar aktif, subyek mengalami kejadian secara langsung berdasarkan pengalaman pribadi. Proses belajar subyek terletak pada triadic reciprocal causation berada dalam interaksi timbal-balik antara lingkungan, person dan perilaku yang kemudian di kontrol oleh agen manusia dan berakhir pada regulasi diri. Dari kesemuanya merupakan faktor yang memepengaruhi atas tindakan subyek yang akan lebih dijelaskan di bawah ini:

a. Lingkungan

Purnomowardani dan Koentjoro (2000) mengatakan bahwa, perilaku seks pranikah adalah manifestasi dari adanya dorongan seks yang dapat diamati secara langsung melalui perbuatan yang tercermin dalam tahap-tahap perilaku seks dari tahap yang paling ringan hingga tahap yang paling berat yang dilakukan sebelum adanya ikatan pernikahan yang sah. Sarwono (2010) mengungkapkan berbagai macam tingkah laku seks yang dimulai dari berkencan, dilanjutkan dengan berpegangan tangan dan berpelukan, kemudian berciuman hingga meraba-raba daerah erogen (payudara/alat kelamin), dan berakhir pada intercourse. A menjelaskan kondisi dimana perlakuan awal yang diberikan oleh B diawali dengan berpegangan tangan di awal hubungannya, kemudian B mengajak berciuman yang saat itu dirasakan A muncul perasaan deg-degan (ndredeg) dan kemudian berlanjut 
dengan berciuman dan memegang payudara dan terus berlanjut hingga ke kemaluan sampai pada akhirnya melakukan hubungan seksual. Hal ini dapat terjadi berdasarkan adanya perlakuan dari lingkungan yang kemudian berproses dalam pikiran diri individu yang merasakan adanya kenikamatan kemudian menghasilkan perilaku yang bervariasi.

b. Person (pribadi)

Menurut Bandura (1978), perilaku manusia disebabkan oleh triadic (timbal balik) yang melibatkan perilaku, kognitif dan faktor lingkungan. Ketiga faktor tersebut "saling menentukan" satu sama lain. Lingkungan yang diciptakan oleh B (pacar) kepada A untuk melakukan hubungan seksual di saat A duduk di bangku SMA merupakan berdampak pada perilaku dan pribadi A. Dimana perlakuan yang diberikan secara berulang- ulang membentuk sebuah pemikiran dengan adanya keinginan yang didasarkan ada Need Afiliasi. Need Afiliasi yaitu A ingin untuk membahagiakan pacar. Menurut Murray (dalam Hall dan Lindzey, 1993), motivasi berafiliasi adalah keinginan untuk mendekatkan diri, bekerja sama atau membalas ajakan orang lain yang bersekutu (orang lain yang menyerupai atau menyukai subjek), membuat senang dan mencari afeksi dari objek yang disukai, patuh dan setia kepada seorang kawan. Kemudian diperkuat dengan perilaku seks yang dilakukan secara berulang-ulang, membentuk sebuah habbit yang berujung pada kebutuhan seksual yang harus terpenuhi.

c. Behavior (perilaku)

Perilaku seksual yang di stimulus dan kemudian di rangsang oleh oleh diri individu melalui proses berfikir menghasilkan sebuah bentuk perilaku Konformitas. Wiggins (1994), Konformitas adalah kecenderungan untuk mengikuti keinginan dan norma kelompok. Hal ini terjadi kepada A untuk mengikuti dan menerima setiap perlakuan yang diberikan oleh B (pacar). Baron dan Byrne (1994) menjelaskan bahwa, konformitas remaja merupakan penyesuaian perilaku remaja untuk menganut norma kelompok acuan, menerima ide atau aturan-aturan kelompok yang mengatur cara remaja berperilaku. Dalam hubungan seksual yang dijalani oleh A \& B membentuk sebuah fase dari yang mulanya melakukan hubungan dengan cara yang pada umumnya dilakukan oleh orang dewasa saat melakukanhubungan seksual, bergeser menjadi penyimpangan seksual yaitu sadomasochism (sadomasokis). Sadomasokis ialah perilaku seksual yang melakukanya dengan menyakiti dan disakiti. Dalam kasus ini, subyek sebagai pihak yang disakiti atau disebut dengan masokis, sedangkan B (pacar subyek) sebagai pelaku sadism atau pihak yang menyakiti. Dalam melakukan hubungan sadomasokis terdapat kesepakatan antara 2 pihak sebelum melakukan hubungan 
seksual, yang mana dalam penjelasan Sears (1994) secara singkat bahwa konformitas ditandai dengan 3 hal yaitu a) Kekompakan, b) Kesepakatan, c) Ketaatan.

Dari ketiga hal tersebut dapat ditarik benang merah bahwa konformitas antara A merupakan suatu bentuk perilaku yang dimunculkan setelah adanya perlakuan yang diberikan oleh B.

\section{Agen Manusia}

a. Kepuasan

Hurlock (1997) menyatakankepuasan hidup adalah keadaan sejahtera dan kepuasan hati, yaitu kepuasan yang menyenangkan yang timbul apabila kebutuhan dan harapan tertentu individu terpenuhi. Selain itu, Hurlock juga menyatakan bahwa kepuasan hidup sering didefinisikan sebagai kebahagiaan yang timbul dari pemenuhan kebutuhan dan harapan, dan merupakan penyebab atau sarana untuk menikmati. Kepuasan dalam melakukan hubungan seksual juga menjadi salah satu faktor yang memengaruhi subyek. Denganasumsi mendapatkan apa yang dibutuhkan dan menikmati dengan hubungan seksual yang dijalani bersama B (pacar subyek) berlanjut pada perilaku yang membentuk sisi baru dari dalam diri subyek. Subyek menyukai hubungan seksual yang menyimpang dengan cara disakiti dan subyek mengaku dapat menikmati hubungan tersebut sehingga merasakan kepuasan tersendiri dalam melakukan hubungan seksual.

b. Kecanduan

Hovart(1989) menjelaskan kecanduan tidak hanya terhadap zat saja tapi juga aktivitas tertentu yang dilakukan berulang-ulang dan menimbulkan dampak negatif. Begitu pula yang terjadi kepada subyek dalam melakukan hubungan seksual merasa kecanduan karena terlalu seringnya melakukan hubungan seksual secara berulang-ulang. Dengan intensitas waktu yang luar biasa. Subyek menjelaskan bahwa rutinitas dalam melakukan hubungan seksual terjadi saat subyek merasa rindu dan paling tidak seminggu jika tidak bertemu diperkuat dengan Cooper (2000) berpendapat bahwa kecanduan merupakan perilaku ketergantungan pada suatu hal yang disenangi. Subyek menambahkan penjelasannya dengan kondisinya jika tidak melakukan hubungan seksual merasakan sesuatu yang aneh, tidak fokus dalam melakukan aktivitasnya dan merasa dirinya bodoh.

\section{Faktor Penyebab}




\section{a. Ketakutan}

Akibat dari hubungan seksuak yang terjadi antara A \& B memunculkan perilaku negatif dengan adanya perasaan takut terhadap diri A, diantaranya : takut terhadap orang tua, takut terhadap teman, takut dijadikan bahan omongan, takut hamil. Ketakutan tersebut muncul akibat di masa SMA subyek tidak memiliki teman, dan subyek merasa dirinya di bully oleh teman-temannya meskipun secara tidak langsung. Sehingga dengan adanya kejadian tersebut, subyek berusaha menutupi dirinya untuk bagaimana menstabilkan dirinya agar tidak dijauhi oleh temannya disaat teman-temannya mengetahui jika kondisi subyek sudah tidak perawan lagi. Kemudian Sarwono (2007) menjelaskan selain menimbulkan dampak yang negatif, seks pranikah juga dapat mengakibatkan terganggunya hubungan seseorang dilingkungan masyarakat seperti dikucilkan oleh teman, hilangnya rasa percaya terhadap laki-laki, khawatir tidak ada lagi yang mau dengan dirinya, menjadi penyuka sesama jenis.

\section{Regulasi Diri}

Fase dalam kehidupan pastilah berubah dan terus berputar selayaknya roda kendaraan. Adapun yang terjadi dengan subyek, subyek berkeinginan untuk bertaubat dan subyek dapat meregulasi dirinya sendiri dengan menggunakan pakaian yang Panjang-panjang menutup aurat sebagai langkah awal untuk mengakhiri hubungannya. Bandura menjelaskan bahwa regulasi diri adalah suatu kemampuan yang dimiliki manusia berupa kemampuan berfikir dan dengan kemampuan itu mereka memanipulasi lingkungan, sehingga terjadi perubahan lingkungan akibat kegiatan tersebut. Menurut Bandura seseorang dapat mengatur sebagian dari pola tingkah laku dirinya sendiri. Selain itu regulasi diri (self regulation) juga merupakan kemampuan mental serta pengendalian emosi. Seluruh perkembangan kognitif, fisik, serta pengendalian emosi dan kemampuan sosialisasi yang baik, membawa seseorang untuk dapat mengatur dirinya dengan baik (Papalia \& Olds, 2001).

\section{KESIMPULAN}

Dari hasil penelitian dapat ditarik kesimpulan sederhana yaitu dinamika psikologis dengan menggunakan triadic reciprocal causation berawal dari lingkungan awal yang diberikan oleh pacar untuk melakukan hubungan seksual membentuk pribadi yang lain melalui proses berfikir merasaka kenikmatan dan munculnya need afiliasi dalam diri subyek dan kemudian menghasilkan perilaku dengan mengikuti dan menerima perlakuan dari pacarnya untuk melakukan 
hubungan seksual pra nikah. Proses kognisi yang kemudian berlanjut pada agensi manusia, dimana subyek merasa puas dalam melakukan hubungan seksual, menikmati rasa sakit saat melakukan hubungan seksual karena adanya kekerasan dalam melakukan hubungan seksual serta kecanduan dengan hubungan seksual yang dilakukan meski subyek mengalami ketakutan terhadap orang tua, teman, hamil merupakan bentuk traumatik dari masa lalu. Juga hilangnya sosok figur kakak yang menjadi penyebab utama terjadinya perilaku menyimpang yang telah dilakukan oleh subyek. Dari kesemua perilakunya kemudian subyek meregulasi diri dengan adanya keinginan untuk bertaubat dan usaha untuk menggunakan pakaian serba panjang untuk menutup aurat.

\section{SARAN}

1. Untuk subyek, berusaha untuk mengelola nafsu dengan melakukan ibadah puasa, mengaji, sholat tepat 5 waktu dan sholat sunnah yang dianjurkan dalam agama islam. Lebih menyibukkan diri dengan melakukan hal-hal positif yang bermanfaat untuk diri sendiri maupun orang lain seperti mengikuti bakti sosial, seminar atau workshop dan lain sebagainya.

2. Untuk peneliti selanjutnya :

a. Disarankan untuk melakukan keabsahan data menggunakan alat bantu heteroanamnesa, yaitu mengumpulkan data informasi tambahan dari pihak- pihak yang terkait, seperti : keluarga, teman dan pasangan dari subyek agar data yang diperoleh lebih akurat.

b. Diharapkan menambah tes psikologi kepribadian seperti: tes inventori, HTP yang mampu menjelaskan secara lebih akurat keabsahan data.

\section{DAFTAR PUSTAKA}

Afriani, I. (2009). Metodologi Penelitian Kualitatif. Bandung : CV. Pustaka Setia.

Chaplin, J.P. (2002). Kamus Lengkap Psikologi. Jakarta : Raja Grafindo Persada.

Creswell, John.W. (2014). Research Design Pendekatan Kualitatif, Kuantitatif dan Mixed, Yogyakarta: Pustaka Pelajar.

Diagnostic and Statistical Manual of Mental Disorders (PDF) (Edisi ke- 4). Washington D.C.: American Psychiatric Association. 1994. Diakses tanggal 24 Maret 2011.

Elizabeth B. Hurlock, (2003). Psikologi Perkembangan : Suatu Pendekatan Sepanjang Rentang Kehidupan. Jakarta : Erlangga. 
Fedoroff, Paul J. MD (2008). "Sadism, Sadomasochism, Sex, and Violence". The Canadian Journal of Psychiatry (Canadian Psychiatric Association) 53 (10) : 637-646.

Feist, Jess ; Gregory J. F (2010). Teori Kepribadian : Theories of Prsonality. Jakarta : Salemba Humanika.

Herdiansyah, Haris. (2012). Metodologi Penelitian Kualitatif Untuk Ilmu- Ilmu Sosial, Jakarta : Salemba Humanika.

Krueger, Richard B. MD; Kaplan, MegS. PhD (2001). "The Paraphilic and Hypersexual Disorders : An Overview". Journal of Psychiatric Practice 7:391-403.

Nevid, Jeffrey S, Spencer A, dkk. 2005. Psikologi abnormal jilid 2 (edisi ke- 5). Erlangga.

Rahardjo, Wahyu. (2017). "Perilaku Seks Pranikah Pada Mahasiswa : Memiliki Peran Harga Diri, Komitmen Hubungan, Dan Sikap Terhadap Perilaku Seks Pranikah". Jurnal Psikologi 44 (2):139-148.

Rahyani, Komang Yuni, dkk. (2012). Perilaku Seks Pranikah Remaja Premarital Sexual Inisiation of Adolescence. Jurnal Kesehatan Masyarakat Nasional. 7 (2) : 180-185.

Santrock, John.W. (2011). Life Span Development, Jakarta : Erlangga.

Setiawan, Rony \& Siti Nur Hidayah. (2008). "Pengaruh Pacaran Terhadap Perilaku Seks Pranikah". Jurnal Soul 1 (2) : 60-69.

Sugiyono, (2008). Metode Penelitian kuantitatife, Kualitatife, dan R \& D. Bandung: ALFABETA.

Suroso, (2004). Teori Belajar Observasi Menuju Belajarn Mempertajam Rasa. Bulletin Psikologi (01) :16-31.

Sutopo, HB. (2006), Metode Penelitian Kualitatif, Surakarta: UNS Press.

Waslam. (2015). "Kepribadian Dalam Teks Sastra: Suatu Tinjauan Teori Sigmund Freud". Jurnal Pujangga 1 (2) :138-151. 